Dept. of Physiology,

Fac. of Vet. Med., Giza, Cairo University,

Head of Dept. Prof. Dr. M. Shaker.

\title{
CHANGES IN THYROID HORMONES DURING THE EGG LAYING CYCLE IN FAYOUMI HENS (With 4 Tables)
}

By
NAHED E. EL-TOUKHY; MAGDA K. MICHAEL; ASMA M. NOUR* and F.A. SOLIMAN
(Received at 4/4/1989)

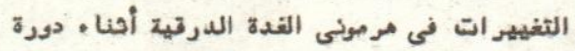

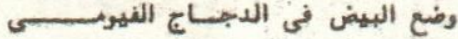

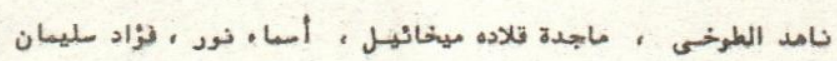

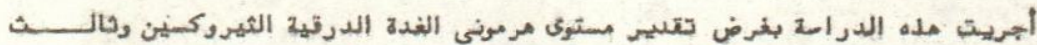

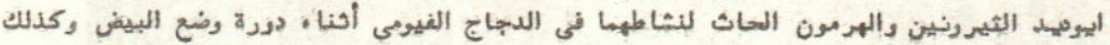

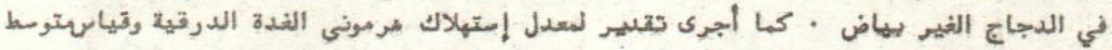

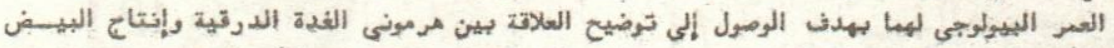

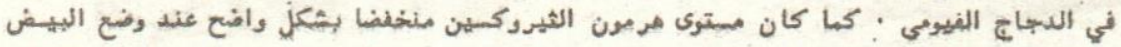

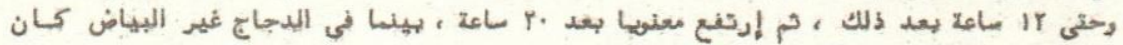

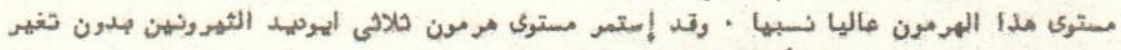

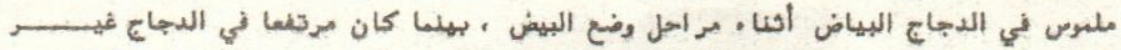

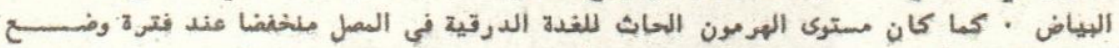

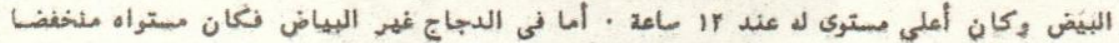

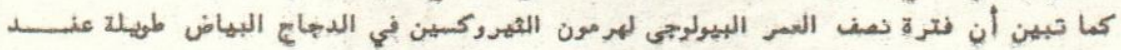

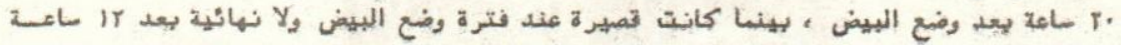

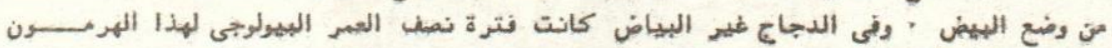

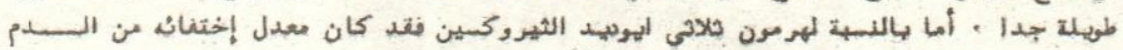

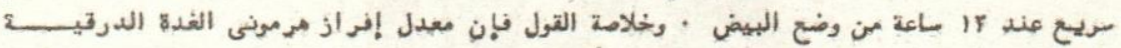

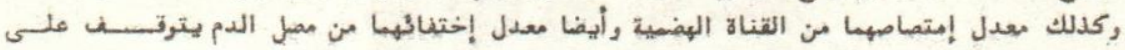

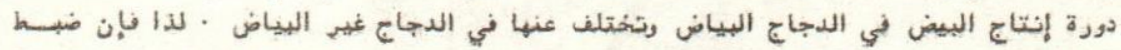

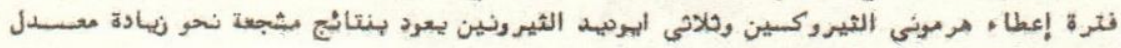

\section{SUMMARY}

The aim of the present study was to determine the levels of $T_{4}, T_{3}$ and TSH in the serum of laying and non laying Fayoumi chickens. The biological half life of exogenous $T_{4}$ and $T_{3}$ was also measured in these chicken to elucidate the relationship between the thyroid hormones and egg production.

*: Radioistops Department, Atomic Energy Authority, Cairo. 


\section{NAHED et al.}

\section{The results obtained revealed that:}

The level of serum. $T_{4}$ during the egg laying cycle varied significantly.

h. Then it reached its maximal $T_{4}$ was relatively low and still low at 12 of $T_{3}$ in serum did not show any at $20 \mathrm{~h}$ after egg laying. The levels of egg laying cycle. Significantly significant variation during all stages non-laying hens.

The lowest level of TSH was observed at egg laying, while the maximal serum TSH was low. The biological half-life of $\mathrm{T}_{4}$ was long in hens $20 \mathrm{~h}$ from egg laying, while
it was shorter at egg laying. In non-laying hens $t_{1 / 2}$ of $T_{4}$ was very long.
The rate of disappearance of $T_{3}$ from circulation The rate of disappearance of $T_{3}$ from circulation of laying hens was more It is

$\mathrm{T}_{3}$ during the egg laying cycle hibition of absorption of $T$ and extends to selective absorption or invariations in utilization of $\mathrm{T}_{4}^{4}$ and $\mathrm{T}_{3}$ at a certain tract. It includes also cycle which is different from non laying hens.

\section{INTRODUCTION}

It has been reported by several investigators that there is a close relationship between thyroid activity of hens and production of eggs (PECZEL et al., 1980; KANSAL and GAGWAR, 1983 and SZELENYLE et al., 1985).

It is also clear that the mechanism regarding control and metabolism of thyroid by AWAD (1979), SOLIMAN et al. (1979 cycle of hens is of great importance. Studies exhibit cyclic activity during the egg laying 1980) showed that the thyroid of hens by 15 to $16 \mathrm{~h}$. This phase of egg laying laying cycle, being very active after ovulation metabolic activities. In this species there appears to be accompanied with intensive hormones (SINPH et al., 1967).

The knowledge of variation in

of absorption and degradation duringroxine and triiodothyronine levels and their rate

to devising the quantity and quality of ovulatory cycle of hens could possibly lead to determine the biological half lifes of egg production. The aim of present study is $\left(T_{3}\right.$ ) during the stages of formation of the exogenous thyroxine $\left(T_{4}\right.$ ) and triiodothronine 


\section{MATERIALS and METHODS}

Thirty eight Fayoumi hens, six months old, with an average weight $1.00+0.20 \mathrm{Kg}$ were used. They were kept in seperate cages in laying metal battaries and feta a layer ration. They ere allowed to drink water ad libitum and exposed to twelve hour light system. The average duration of egg laying cycle was determined, which took 30.5 $h$ on average. The hens were classified into three groups (10 each) according to the time of egg laying, namely zero hour (representing the time of egg laying), 12 and 20 hour after egg laying. Fourth group of eight non laying hens was also used in this study. Blood samples from wing vein were collected from all hens at a fixed time around nine oclock before administration of the hormones to avoid diurinal variation of thyroid hormone level in blood (SARDAVSKY and BENSADOUN, 1971).

According to the time relation to egg laying, the birds were given orally a mixture of 50 ug L-thyroxine $\left(T_{4}\right)$ and 5 ug L-triiodothyronine ( $\left.T_{3}\right)$ (Gloxo). The horomones were included in cocked starch gell suspension and introduced into the crop by a rubber hens.

Other two samples were then obtained from all birds after 4 and 5 hours from administration of the hormones. This timing was selected to. represent post-resorptive stage. The serum samples were collected and kept frozen at $-20^{\circ} \mathrm{C}$.

Quantitative determination of $\mathrm{T}_{4}$ and $\mathrm{T}_{3}$ was accomplished by enzyme linked immunoabsorbant assay (Elisa) according to WOOO (1980). Serum thyrotrophic hormone (TSH) in chicken was determined by radioimmunoassay according to HERSHMAN and PITTMAN
(1971).

Computation of biological half-life of hormones were done.

\section{RESULTS}

The results obtained from table (1) revealed that, at egg laying time, $T$ level in serum was relatively low $(39.9 \mathrm{ng} / \mathrm{ml}$ ) and lowest at $12 \mathrm{~h}$ after egg laying (12.0 $\mathrm{ng} / \mathrm{ml})$. It reached its maximal level at $20 \mathrm{~h}$ after egg laying $(205.1 \mathrm{ng} / \mathrm{ml})$. In case of non-aying hens, serum $T_{4}$ level was $45.4 \mathrm{ng} / \mathrm{ml}$. $T_{3}$ level in serum did not show serum $\mathrm{T}_{3}$ was observed in all stages of egg laving cycle. Significantly high level of

of non laying hens which was $20.7 \mathrm{ng} / \mathrm{ml}$.

1) which correlated of hens showed cyclic variations during egg laying cycie (Table $\left(0.39+0.07\right.$ u.i.u/ml) was observed at serum $T_{4}$ levels. The lowest level of serum TSH a time around $12 \mathrm{~h}$ after egg laying laying, while the maximum level was observed was low (0.79 u.i.u./ml). Absorption of $\mathrm{T}_{4}$ as indicated from $4 \mathrm{~h}$ post resorptive stage was very high at
$20 \mathrm{~h}$ after egg laying and very low at $12 \mathrm{~h}$ after laying (Table 2). In non laying hens
and in hens at egg laying time, the rate of absorption and in hens laying time, the rate of absorption of $\mathrm{T}_{4}$ was moderate. In contrast

Assiut Vet.Med.J. Vol. 22, No. 44, January, 1990. 


\section{NAHED et al.}

to this, absorption of $\mathrm{T}_{3}$ was increased with a high serum level at $4 \mathrm{~h}$ after ingestion of hormones in hens at $12 \mathrm{~h}$ after egg laying (Table 3). Lower rate of absorption of $\mathrm{T}_{3}$ were noticed at egg layingtime and at $20 \mathrm{~h}$ after egg laying. Maximal absorption of $\mathrm{T}_{3}$ was observed in non-laying hens (Table 3 ).

After $5 \mathrm{~h}$ from ingestion of hormones, it was found that, serum level of $T_{4}$ showed a decrease during the laying cycle except at $12 \mathrm{~h}$ from egg laying. this level showed also a mild decrease in non-laying (Table 2). Serum $\mathrm{T}_{3}$ level at $5 \mathrm{~h}$ from ingestion of hormones decreased slightly at egg laying and obviously at $20 \mathrm{~h}$ it was not different from its level at $4 \mathrm{~h}$. The biological half life $\left(\mathrm{t}_{1 / 2}\right)$ was long in hens $20 \mathrm{~h}$ from egg $12 \mathrm{~m}$ ), while it was shorter at egg laying $(26.4 \mathrm{~m})$ and infinite in hens after rate of disappearance of non-laying hens $t / 1 / 2$ of $T_{4}$ was very long $(702.8 \mathrm{~m})$. The $12 \mathrm{~h}$ after egg laying with $T_{3}$ from the circulation of laying hens was more rapid at laying. In case of hens after $1 / 20 \mathrm{~h}$ from laying $\mathrm{t}_{1 / 2}$ of $\mathrm{T}_{3}$ was $44.8 \mathrm{~m}$ at time of egg In non-laying hens the $t$ of $T_{3}$ from laying, the $t_{1 / 2}$ of $T_{3}$ was infinite (Table 4).

Table (1): The level of serum $\mathrm{T}_{4}$ and $\mathrm{T}_{3}$ and TSH in laying and nonlaying Fayoumi chickens.

\begin{tabular}{|c|c|c|c|c|}
\hline \multirow{2}{*}{ Hormones } & \multicolumn{3}{|c|}{ Laying hens } & \multirow{2}{*}{$\begin{array}{l}\text { non-lay- } \\
\text { ing hens }\end{array}$} \\
\hline & \multicolumn{3}{|c|}{ Time after egg laying ( hour) } & \\
\hline \multirow[b]{2}{*}{$\mathrm{T}_{4}(\mathrm{ng} / \mathrm{m} 1)$} & 0 & 12 & 20 & \multirow{3}{*}{$\begin{array}{l}45.4^{\mathrm{b}} \\
\pm 6.8^{8} \\
20.7^{\mathrm{b}}\end{array}$} \\
\hline & 39.9 & $12.0^{a}$ & $205.1^{*}$ & \\
\hline $\mathrm{T}_{3}(\mathrm{ng} / \mathrm{m} 1)$ & $\begin{array}{r} \pm 10.0 \\
1.8^{a}\end{array}$ & $\begin{array}{l} \pm 3.5 \\
2.2^{\mathrm{a}}\end{array}$ & $\begin{array}{r} \pm 45.8 \\
2.2^{\mathrm{a}}\end{array}$ & \\
\hline \multirow[t]{2}{*}{ TSH (ng/m1) } & $\begin{array}{l} \pm 0.1 \\
0.39^{a}\end{array}$ & $\frac{ \pm 0.5}{3.94^{*}}$ & $\begin{array}{r} \pm 0.2 \\
1.10\end{array}$ & $\begin{array}{c} \pm 5.1 \\
0.79\end{array}$ \\
\hline & \pm 0.07 & \pm 0.56 & \pm 0.40 & \pm 0.04 \\
\hline
\end{tabular}

\pm Standard error

* Significantly higher than other group in the same raw at $P<0.01$.

a) The lowest level recorded.

b) Significantly higher than a in the same raw at $p<0.05$. 


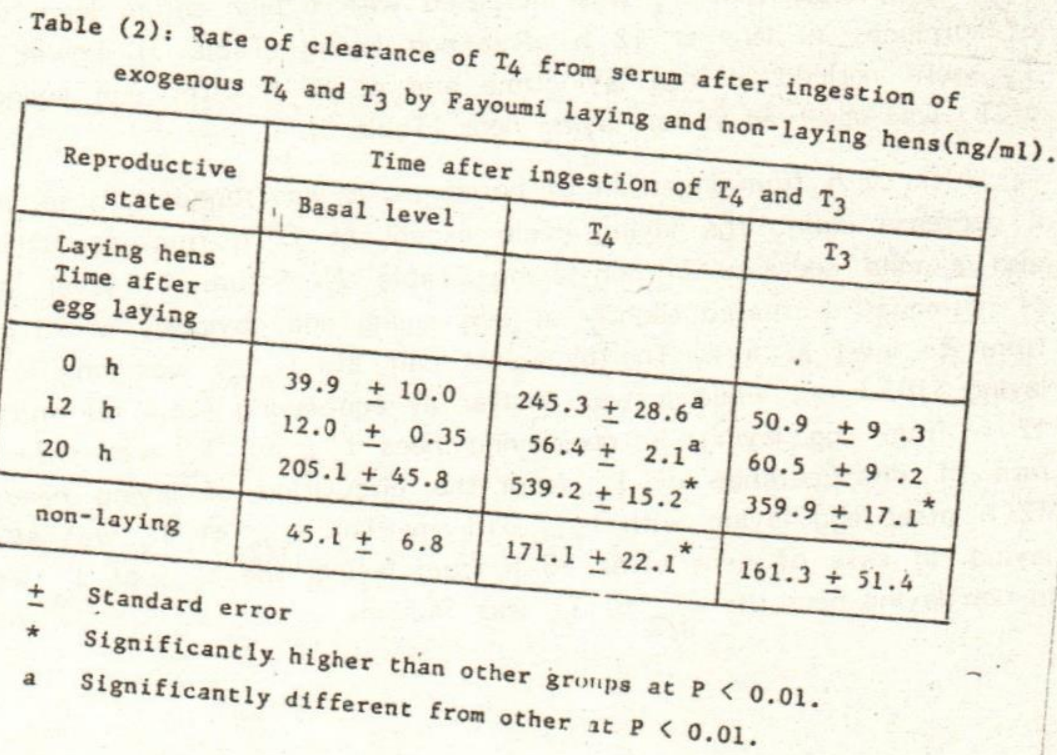

Table (3): Rate of clearance of $\mathrm{T}_{3}$ from serum after ingestion of

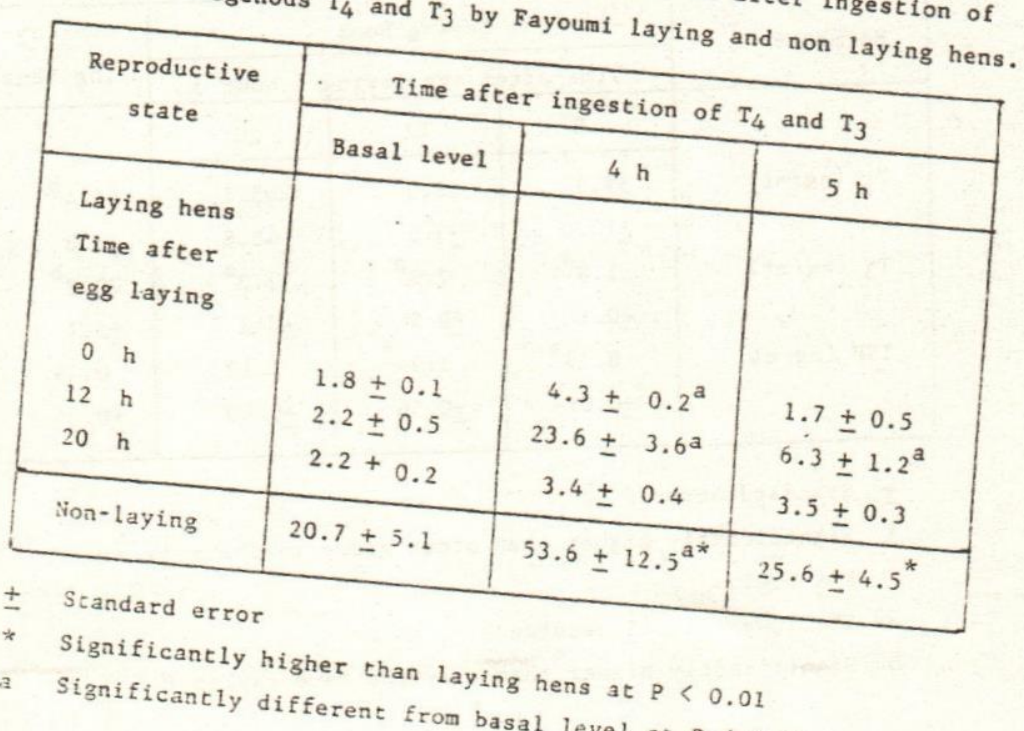




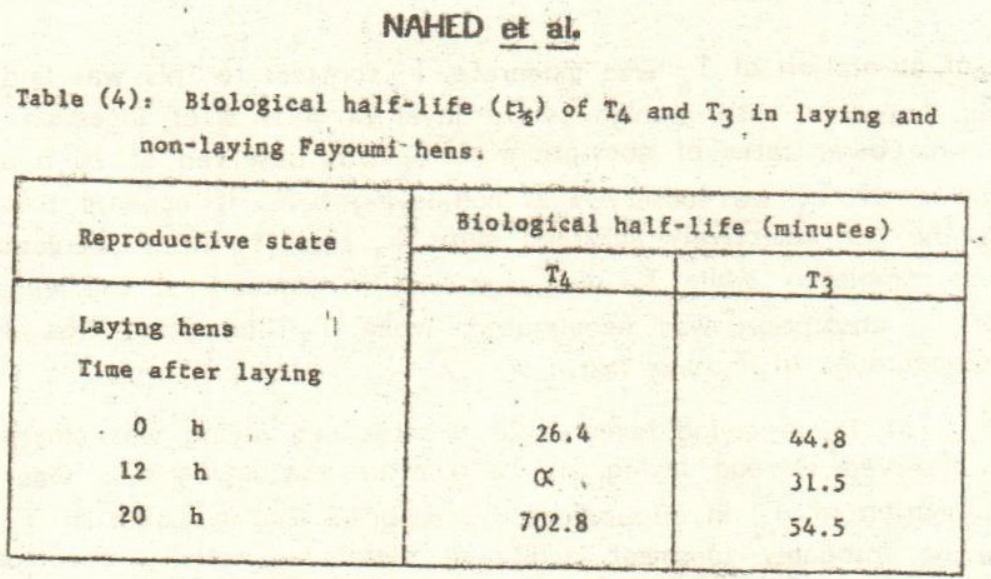

\section{DISCUSSION}

The present finding revelaed that the thyroid gland of Fayoumi hens exhibited cyclic variations in their activity as correlated with egg laying. Disappearance of $T_{4}$ and $T_{3}$ from circulation was also correlated with reproductive state of hens. At egg laying time serum $\mathrm{T}_{4}$ level was relatively low and lowest at $12 \mathrm{~h}$ after egg laying, while it increased maximally at $20 \mathrm{~h}$ after egg laying. $T_{3}$ levels in serum did not show significant variations during all stages of egg layin cycle. In non-laying hens, serum $\mathrm{T}_{4}$ level was significantly less than that observed at the time of $20 \mathrm{~h}$ after egg laying but higher than that observed at $12 \mathrm{~h}$ after egg laying. These findings are inagreement with those obtained by AWAD (1979) and SOLIMAN et al. (1980).

Serum TSH level of Fayoumi hens also showed cyclic variations during the egg laying cycle, which correlated inversely with $T_{4}$ level. The interaction between TSH and thyrold hormones appears clearly, at the stage $12 \mathrm{~h}$ and $20 \mathrm{~h}$ after egg laying. It was noticed that at $12 \mathrm{~h}$ serum $T_{4}$ was lowest and $T_{3}$ not changed. At this time TSH level was highest. This increased secretion of TSH resulted in the subsequant high serum $T_{4}$ at $20 \mathrm{~h}$ after egg laying. It can appear clearly that $T_{4}$ rather than $T_{3}$ can actively play a role in the control of secretion of TSH in chicken. The results of MELLEN and WENTWORTH (1959) indicated that $T_{4}$ was more potent than $T_{3}$ in reducing TSH secretion in fowl. They also found that, the dose of $\mathrm{T}_{4}$ which blacked TSH from the pituitaries was smaller than that required by $T_{3}$.

In non-laying hens, the amount of $T_{3}$ increased about 11 folds that observed in laying hens at all stages of egg laying cycle. Previous investigations revealed that cessation of egg production and molting were always accompanied with significant increase in $T_{3}$ level in molting hens (SZELENYLE et al., 1985). Further study showed that injection of $T_{4}$ to hens, the egg production remained constant but injection of $T_{3}$ decreased
egg production (VERHEYEN et al., 1986).

Absorption of $\mathrm{T}_{4}$ as indicated from $4 \mathrm{~h}$ post resporptive stage was very high at $20 \mathrm{~h}$ and very low at $12 \mathrm{~h}$ after egg laying. In non-laying hens and at egg laying time 
their rate of absorption of $\mathrm{T}_{4}$ was moderate. In contrast to this was find that absorption of $T_{3}$ was increased with a high serum level at $4 \mathrm{~h}$ after ingestion of hormones in hens at $12 \mathrm{~h}$. Lower rates of absorption of $T_{3}$ was observed at $20 \mathrm{~h}$ after egg laying. Maximal intake of $\mathrm{T}_{3}$ was observed in non-laying hens. It appears that at $12 \mathrm{~h}$ after egg laying, the hen selectively absorped more $T_{3}$ than $T_{4}$ from circulation at this stage was blocked completely while $\mathrm{T}_{3}$ was removed. On contrary at the stage of $20 \mathrm{~h}$ after egg laying $T_{4}$ absorption was accelerated, while $T_{3}$ absorption was delayed and the rate of disappearance of $\mathrm{T}_{4}$ was fast.

The $t_{1 / 2}$ of $T_{4}$ in laying hens at $20 \mathrm{~h}$ after egg laying was almost 4 time longer than that observed at egg laying, at $12 \mathrm{~h}$ after egg laying $t_{1 / 2}$ was not measurable because stagnation of $\mathrm{T}_{4}$ in circulation. this suggests that turnover of $\mathrm{T}_{4}$ is more rappid at egg laying, probably to meat additional metabolic activity accompanied with act of laying. The $t_{1 / 2}$ of $T_{3}$ ranged between 31.5 and $44.8 \mathrm{~m}$ during early stages of egg laying cycle. In non laying, the $t_{1 / 2}$ of $T_{4}$ was prolonged and $t_{1 / 2}$ of $T_{3}$ was near from one hour. This indicates increased utilization of $T_{3}$ rather than $T_{4}$ by these birds.

In conclusion, it appears that thyroid gland is closely related with reproductive states of chicken. It is not simply a matter of increased or decreased secretion of its hormone during a certian phase of reproduction during egg laying cycle, but extends to selective absorption or inhibition of absorption of $T_{4}$ and $T_{3}$ by alimintary tract. It includes also variation in utilization of $\mathrm{T}_{4}$ and $\mathrm{T}_{3}$ at certain time in egg laying cycle which different from non-laying hens.

\section{REFERENCES}

Awad, A.K. (1979): Thyroid-ovary relationship in laying hens. M.V.Sc. Animal Physiology, Cairo University.

Hershman, J.M. and Pittman, J.A. (1971): Utility of radioimmunoassay of serum thyrotrophin in man. Ann. Int. Med. 74: 481.

Kansal, M.L. and Gagwar, P.C. (1983): Eggect of spring and summer seasons on egg production responses in domestic fowl (Gullus domesticus). Indian Journal of Animal Sciences 55(11): 1265-1270.

Mellen, W.T. and Wentworth (1959): The relationship between certain thyroid characterstics of pullets and their egg production; body weight and evironment. Poult. Sci., 38: $620-624$.

Peczel, P.; Pethes, G. Rudas, P. (1980): Interrelationship between thyroid and gonadal function in female Japanese guail kept under short and long phatoperiods. J. Endocrinol. $87(1)$ : 55-63.

Sardovsky, R. and Bensadoun, A. (1971): Thyroid hormones in the plasma of the rooster (Gallus domesticus). Gen. Comp. Endocrinol. 17: 268-274.

Sinph, A.; Reieke, E.P. and Ringer, R.K. (1967): Thyroxine and Triiodo thyronine turnover in chicks, bob-white and Japanese guail. Gen Comp. Ocr. Endocrinol. 9: 353-361.

Assiut Vet.Med.J. Vol. 22, No. 44, January, 1990. 
Soliman, F.A.; Sohair, Y.S.; El-Moughy, S.A. and Awad, A.K. (1979): Cyclic variations in thyroid activity during the ovulatory cycle of laying hens. Egypt, Vet. Med. J. $27(27): 269-278$.

Soliman, F.A.; Sohair, Y.S. and Awad, A.K. (1980): Thyroid ovary relationship in laying hes. Zbl. Vet. Med. A., 27, 544-554.

Szelenyle, Z.; Pethes, G.; Peezely, P. (1985): Seasonal changes in the plasma concentration of sexual steriods, corticosterone and thyroid hormone in the hen with special respect to the moulting period. Acta, Veterinaria Hungarica. 33(3/4): 189-198.

Verheyen, G.; Decupere, E.; Kuhn, E.R. and Hereman, M. (1986): Dissociation of the effect of thyroxine and triiodothyronine in relation to the hal, egg laying and moult in hens. Acchiv Für Experimentolia Veterinarmedizin, 40(2): 250-259.

Wood, W.G. (1980): Serum triiodo-thyronine $\left(T_{3}\right)$ and thyroxine $\left(T_{4}\right)$ assays using the Mwnich model. J. Clin. Chem. and Clin. Biochem., 18: 811. 